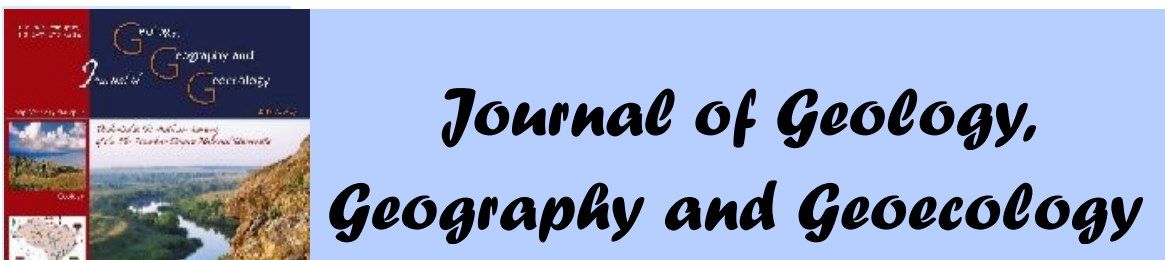

Journal home page: geology-dnu-dp.ua

\title{
Labile technogenic geological system of the flooded Shevchenko salt mine (Ukraine)
}

\author{
Larysa P. Bosevska ${ }^{1}$, Anirban Chowdhury ${ }^{2}$ \\ 1 Ukrainian Salt Research Institute, Bakhmut, Ukraine, e-mail: bosslara@gmail.com \\ 2 Sidhu Kanu Birsha University, Purulia, India, e-mail: anirbangeo@hotmail.com
}

\section{Received 15.05.2018;}

Received in revised form 29.05.2018;

Accepted 16.06.2018

\begin{abstract}
basic mining and geological data as well as the results of the long-term complex ecological-mining-geological monitoring.The paper describes both the geology of the mine area and the condition assessment of the mine including its shape, parameters, and layout. In addition, scientific interpretation of the mechanism of multi-act intrasystem destructive processes, which have been taking place in the last few decades are provided. Natural and technogenic factors determining the development of the created technogenic geological system (such as man-made karst and critical geomechanical deformations) are summarized and analysed. Predictive evaluation of the time-dependent deformation processes development has been carried out using theexisting methodology for assessing the geomechanical condition of the mined-out area of the salt massive. Correctness of the method for evaluation of stability of the unsupported workings system currently in use for the Artyomovsk rock salt deposit development has been confirmed. This work concerns the scientific problems of maintenance of the geo-ecological safety in the densely populated areas disturbed by underground salt mining. Hereinabove research results add information and analytical base to improve the deformation control system for ductile salt layers in various dynamic conditions of man-caused and natural loads. It is shown that such control is required for the aim of reduction of environmental risks and ensuring the safe operation of salt deposits, salt resources protection as well as infrastructure objects at the Earth's surface nearby sites of modern salt mining activity.
\end{abstract}

Key words: rock salt, salt mine, destructive processes, deformations, Earth's surfacesubsidence,monitoring

\section{більн техногенно-геологічн систем території з топленного соляного рудник евченко ( кр їн )}

. . осевск $я^{1}$, нирб н удхури ${ }^{2}$

1 кр инский н учно-исследов тельский институт соляной промышленности, хмут, кр ин e-mail: bosslara@gmail.com

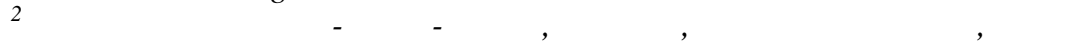
e-mail: anirbangeo@hotmail.com

нот ція. д ній роботі предст влен н логов еколого-гірничо-геологічн модель л більної техногенно-геологічної системи, створеної н території з топленої соляної ш хти імені евченк в меж х ртемівського родовищ к м'яної солі, н йбільшого родовищ солі в вропі. підст ві н літичної обробки і компіляції первинних гірничо-геологічних д них, т кож результ тів трив лого комплексного еколого-гірничо-геологічного моніторингу предст влено опис всіх елементів системи в їх вз ємозв'язку і вз ємодії і д но н укове тлум чення мех нізму б г то ктних внутрішньосистемних деструктивних процесів, що протік ють протягом декількох десятиліть. 3 г льнені т про н лізов ні природні т техногенні ф ктори, що визн ч ють розвиток створеної техногенно-геологічної системи (техногенний к рст і критичні геомех нічні деформ ції соляного м сиву). икон н прогнозн оцінк розвитку деформ ційних процесів з використ нням існуючої методики оцінки геомех нічного ст ну відпр цьов ної ділянки соляного м сиву. ідтверджено коректність з стосовув ної методики оцінки стійкості системи нез кріплених виробок при розробці ртемівського родовищ к м'яної солі. обот 3 чіп є н укові проблеми з безпечення геоекологічної безпеки в густон селених р йон х, порушених підземним видобутком к м'яної солі. икл дені результ ти досліджень поповнюють б зу інформ ційно- н літичного з безпечення системи упр вління деформ ціями пл стичного розчинного середовищ соляних товщ в різних дин мічних режим х техногенних і природних 
н в нт жень для зниження екологічних ризиків і з безпечення безпечної експлу т ції родовищ солей, охорони соляних ресурсів, т кож об'єктів інфр структури н земній поверхні поблизу ділянок суч сної розробки к м'яної солі.

лючові слов : к м’ян сіль, солян коп льня, деструктивні процеси, деформ цї̈, осід ння поверхні, моніторинг

Introduction. Problem setting. Deep scientific investigation of the geological-environmental strain due to man-made intervention into salt strata is a matter of concern for present day salt mining practice. It is caused by the growing multilateral interest in salt strata both as a raw material base for rock salt extraction and as an environment for various engineering objects creation such as hydrocarbon and waste storage facilities (including radioactive ones), speleosanatoriums, touristic objects, etc.

A generalized task of many contemporary studies concerning salt deposits is the enhancement of the theory of environmentally acceptable manmade intervention into salt strata. Some important tasks of the environmental safety and commercial goals are in conflict, in particular as it relates to the technical requirements for a reasonable permissible recovery ratio of minerals (rock salt). Particularly an acute issue is finding one of the correct methodology for controlling the rate of strain in salt rocks at all stages of technogenic interference for ensuring their safe level. This research direction is considered to be of high significance for the salt mining activity within densely populated territories since uncontrolled deformations can entail any serious ecological and economic damage endangering the important objects of social and economic infrastructures and people's lives.

All aspects of technogenic deformations of the rock massif and their adverse ecological impact are the separate theoretical and practical issues aimed at developing a system of integrated control and forecasting of these deformation processes.Different scientist around the world has devoted their works to these issues. Salt massifs' geomechanics and physical-mechanical properties of rock salt determining geomechanical processes are considered in the works of Michael L. Jeremic and Saeed Nazary Moghadam ( nada), A. . Baryakh and V.A. Asanov (Russia), Alla R. Seraya (Ukraine) and many others. Issues of the natural and technogenic karst are detailed in the works of G.V. Korotkevich (Ukraine), Anthony H.Cooper and F. Gutiérrez (Great Britaine) and others. Interaction of different aspects of strain manifestation and consequences as well as monitoring results for deformable areas influenced by the technogenic object created inside salt strata are presented in the works of T.G. Brooks, N. J. o'Riordan and Jamie K. Pringle (Great Britain), Dmytro P. Khrushchov (Ukraine), Mihaela Toderas (Romania), Gloria Desir (Spain), Astrid Gessert and Thomas Schicht (Germany), M. Cała and A. Tajduś (Poland), M.
Karimi-Jafari and Pierre Berest (France), Bill Shefchik (USA) and others.

It is important to analyze a significant number of examples of deformation processes development associated with the construction and exploitation of various objects in salt strata in order to create the correct system of salt massif deformation control. Though the manifestation of the destructive processes and land degradation are different in every case, because of the various geological and hydrogeological conditions and various technology applied, it reveals similarities in similar technogenic geological systems (further in the text - TGS).

There is insufficient complex research results dealing with salt environment deformations and the Earth's subsidence monitoring on the territories of man-made objects within salt massifs. Based on long-term monitoring, this work provides a detail description of the active deformation processes and concomitant ecological changes ongoing within the area of old flooded Shevchenko salt mine that exploited the thickest bed of the Artyomovsk rock salt deposit.

The objective of the paper is to present analog model of the technogenic geological system (TGS) of the Shevchenko flooded salt mine area and to interpret mechanisms and factors of its development.

As already mentioned in general, the significance of the work is related to the need for further development of the risk control methodology related to technogenic interference in salt massifs associated with new technologies, to achieve a balance between scientifically based technical requirements and commercial benefits (Brooks et al, 2006).

But the performed research urgency is further strengthened due to the fact that this flooded mine is located in the central part of the modern operation field and its location is adjacent to such an important infrastructure facility as the railway (110 $\mathrm{m})$. A safety pillar with reasonable thickness detaching the flooded mine workings from today operational areas of mine \# 4 has been left around this old mine.

It should be noted, there is one more reason of this paper urgency at popular science level. The fact is that some media (including Internet-sources) have presented salt lakes above the flooded salt mine as a certain anomalous zone and have included it in numerous lists of mystical zones of Ukraine. This point also requires the scientific clarifications. 
Geological and hydrogeological settings. The geology and hydrogeology of the Artyomovsk rock salt deposit is known quite well. In geological and structural terms, it is located within Bakhmut basin of the Dnieper-Donetsk depression. The geology of the deposit is simple: it is composed of a few subhorizontal rock salt beds belonging to Slavyanska suite of the Lower Permian salt-bearing formation (P1sl) and it is confined to the salt-bearing suite lying closest to the Earth's surface (from $69 \mathrm{~m}$ to $600 \mathrm{~m}$ ).

Slavyanska suite $\left(\mathrm{P}_{1} \mathrm{sl}\right)$ includes a complex ofcharacteristic evaporitic sediments (26 rock salt seams, anhydrite and gypsum layers) rhythmically intercalated by carbonate rocks (limestone, dolomite, marl) as well as terrigenous rocks (argillite, siltstone). The salt-bearing suite is monoclinal, dipping north or north-west at $2-5^{\circ}$. The thickest industrial beds are named (from the bottom to the top): Under-Bryantsevsky Bed (UBB) with thickness of about $31 \mathrm{~m}$, Bryantsevsky Bed (BB) with thickness up to $41.2 \mathrm{~m}$ and Above-Bryantsevsky Bed (ABB) with average thickness of $31.9 \mathrm{~m}$. Now only two beds with the highest industrial quality (BB and UBB) are being extracted.
The geological section of the salt-bearing lavyanska suite, in its upper part is inconsistent stratigraphically. Slavyanska suite sediments are covered by Kramatorska suite of the Lower Permian $\left(\mathrm{P}_{1} \mathrm{krm}\right.$, chemogenous deposits: gypsum, anhydrite), Dronovs$k a$ suite of the Lower Triassic $\left(\mathrm{T}_{1} \mathrm{dr}\right.$, predominantly terrigenous sediments: siltstone, mudstone, largely fractured sandstone) and Quaternary sediments (loesslike loam, red-colored clay, alluvial deposits of rivervalleys with common thickness from 5 to $40 \mathrm{~m}$ ).

Due to weakly-inclined bedding and unconformity all salt beds contact the water horizons in overlying rocks at the outcrops below the overburden. At the sites of this contact leaching zones of ribbon-like shape are formed (Fig. 1). They are represented by ancient and modern leaching breccia, which is loose and cavernous and, subsequently essentially water permeable. The hydraulic connection between underground mining workings and the leaching zones is extremely dangerous since it irrevocably lead to the development of a deep manmade karst and finally flooding of the mine (Bosevska and Mishchenko, 2009).

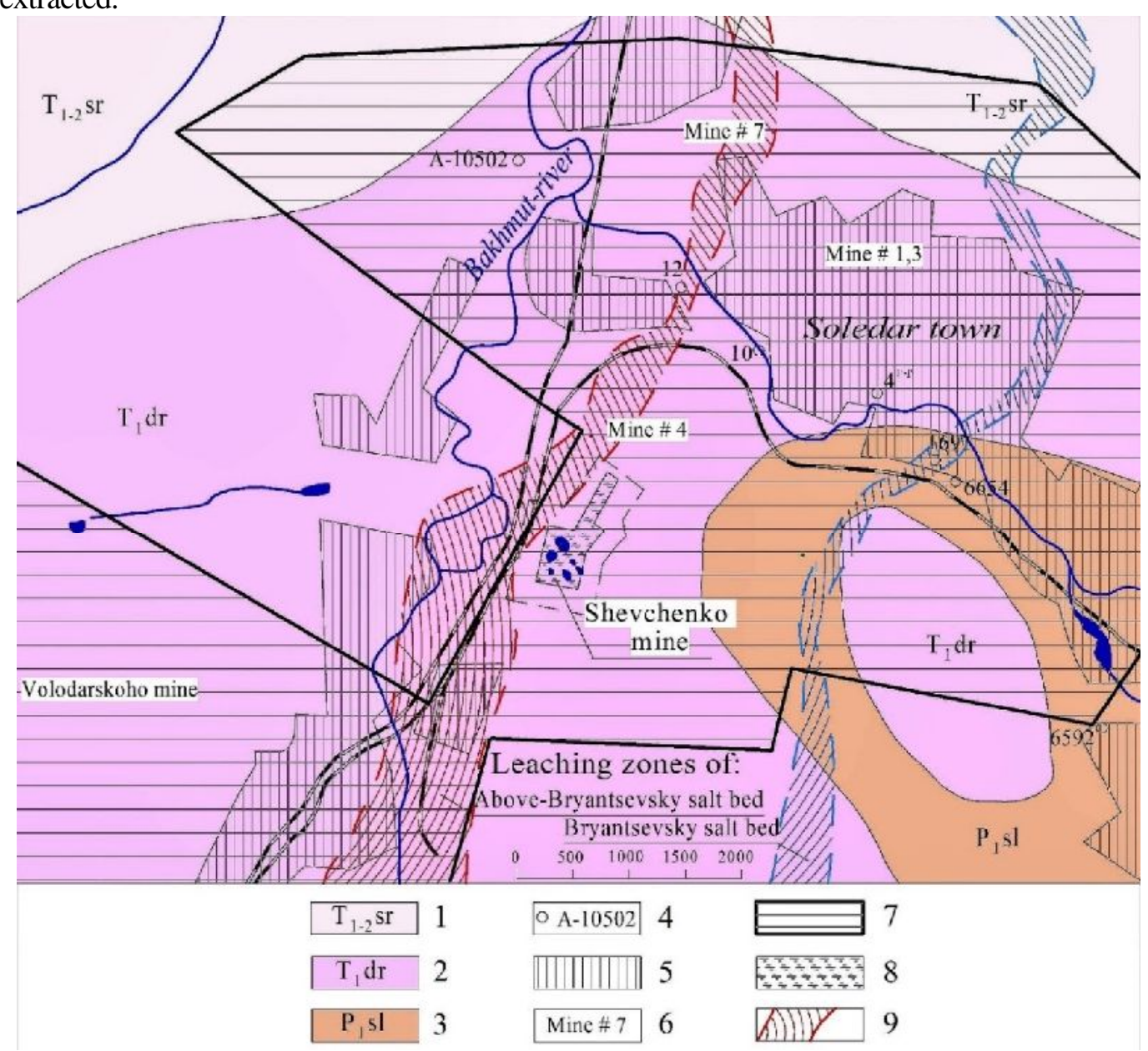

Fig. 1. Geological map of the Artyomovsk rock salt deposit mapping the flooded Shevchenko salt mine and modern mine working fields 1 - Serebryanska suite (undivided Lower and Middle Triassic): sandstone, argillite-like clay; 2 - Dronovska suite (the Lower Triassic): sandstone, siltstone, mudstone; 3 - Slavyanska suite (theLower Permian): rock salt, anhydrite and gypsum with a subordinate amount of carbonate rocks (limestone, dolomite, marl), argillite, siltstones; 4 - exploration wells; 5 - inhabited areas; 6 - operating modern mines; 7 - modern mining area stated by the special permits for subsoil use of State Enterprise "ARTYOMSOL"; 8 flooded mine workings of the Shevchenko mine; 9 - leaching zones of salt beds defined by exploratory works in 1988 - 1991 
The hydrogeology of the deposit is also simple for interpretation: the thick salt massive is a regional impervious bed. All over-salt rock mass is an unified areally, but not uniform aquifer complex that contains the hydraulically connected water horizons from the upper part of the Slavyanska suite to the Quaternary aquifers. Reservoir rocks for the aquifers are the salt leaching breccia (Fig. 2), karstgypsum, fractured sandstones as well asQuaternary sands and loams. According to hydrodynamic characteristics, all aquifers are confinedandunconfined. Some aquifers have the heads of 50 meters and more. Prior works have establishedcontinuous hydraulic connection between all aquifers within local sites. The main direction of pressure flow of water is from the bottom upwardsup to Quaternary aquifers.

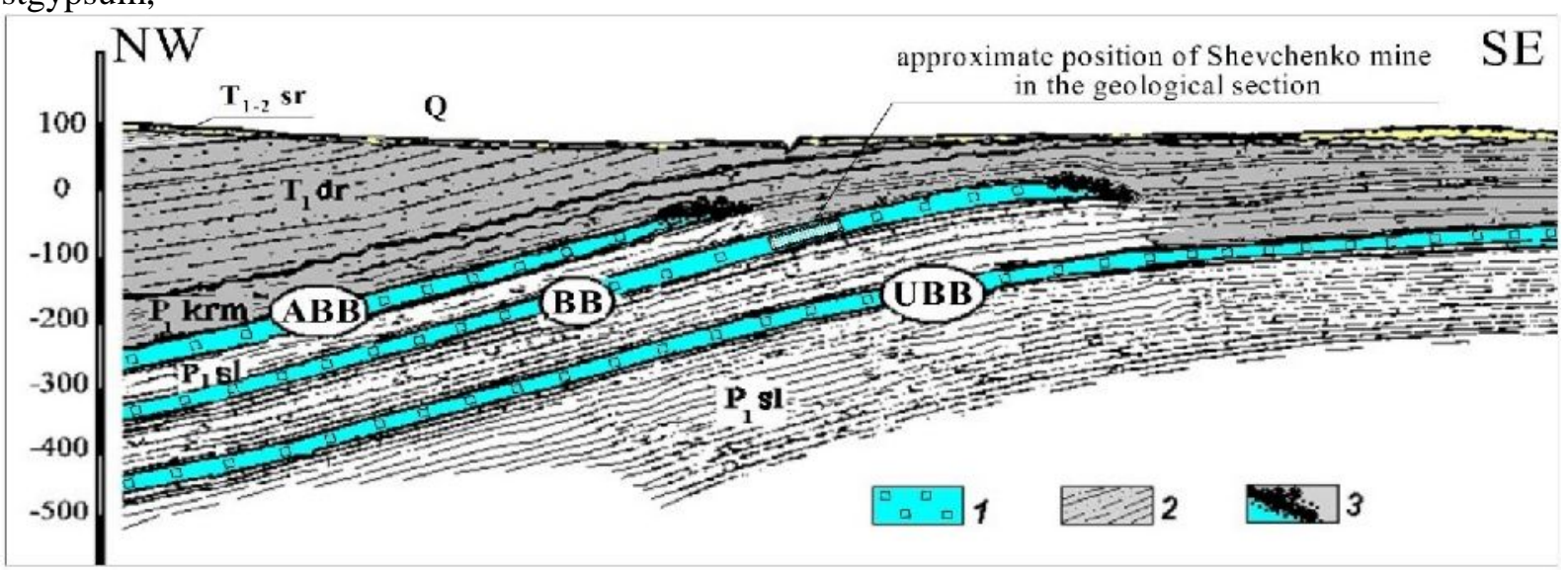

Fig.2. Schematic cross-section of Artyomovsk rock salt deposit (PSA “Donbassgeology", 1988)

(the vertical scale is five times less than horizontal one)

1 - industrial salt beds: Bryantsevsky bed (BB), Under-Bryantsevsky bed (UBB), Above-Bryantsevsky bed (ABB); 2 - waterflooded terrigenous and terrigenous-chemogenic strata (clay, sandstone, argillite, gypsum, anhydrite) $\left(\mathrm{T}_{1} \mathrm{dr},{ }_{1} \mathrm{krm}\right) ; 3-\mathrm{leaching}$ zones of the salt beds; 4 - Quaternary sediments.

Due to the presence of soluble rocks in geological profile, the chemical composition of groundwater varies widely. The most mineralized waters come from the leaching zones of salt beds (up to 250 $\mathrm{g} / \mathrm{l}$ and more) and gypsum layers groundwater. The chemical composition of the water of interconnected aquifer complex is sulphate-chloride calcium-sodium or chloride calcium-magnesium-sodium.

Geological conditions predetermine the nonpoint natural leaching process of upper salt bed (ABB) in some parts of the deposit and natural gypsum karst processes in over-salt rock mass.

Historical background on functioning of the Shevchenko mine. The Shevchenko mine is one of the oldest underground mines that have been established in the Artyomovsk rock salt deposit since 1882. It is located at the right bank slope of the Bakhmut River valley near Soledar town; it is $\mathbf{1 . 2}$ miles from Kudryavka railway station.

The location of this mine was chosen spontaneously without geological foundationsdue to the lack of the necessary geological and hydrogeological data during the period of pre mining operation. As a result, the mine operating conditions were dependent on a random factor. Two mining shafts of $170 \mathrm{~m}$ depth turned out to be located near the modern leaching zone of the overlying ABB. During the construc-tion, the mine shafts crossed two water-abundant aquifers: 1 - aquifer of Dronovska suite gypsum (depth of $28.3 \mathrm{~m}$, yield of 64.3 $\mathrm{m}^{3} /$ hour); 2 - aquifer of Slavyanska suite gypsum and of the leaching zones of ABB (depth of $89.5 \mathrm{~m}$, yield of $3.8 \mathrm{~m}^{3} /$ hour).

Waterproofing works in the shafts were not performed properly, so the rock salt extraction was carried out under the condition of constant water drainage. Therefore, the mining was accompanied by increasing inflows of water to the shafts; and the total amount of incoming water reached 1560 $\mathrm{m}^{3} /$ day. Incoming waters did not reach salt bed, because the water was captured in different ways, by using a specially constructed drainage system in the shafts. Fresh water was discharged to surface waterswhile brines were directed into the special settling basins on the surface.

The mine exploited the Bryantsevsky bed lying at a depth interval of $120-180 \mathrm{~m}$. Salt extraction reached 450,000 t/year. Mining works were carried out using classic room-and-pillar system with remnant support pillars. The following mining system parameters were applied: chamber sizes 15 $17 \mathrm{~m}$ (width) $\times 23.5-33 \mathrm{~m}$ (height $) \times 300-600 \mathrm{~m}$ (length) and very long interchamber pillars (rib pillars), which has the width of $9-12 \mathrm{~m}$.

The overall minefield was $1100 \mathrm{~m}$ long and about $350 \mathrm{~m}$ wide. The total volume of mining workings reached $5.2 \mathrm{mln} \mathrm{m}^{3}$ and the floor of workings was $200.000 \mathrm{~m}^{2}$. 
The mine had been functioning for almost 60 years. In autumn 1941, due to military operations of the Second World War, the mine stopped working and drainage was forcibly terminated. From that time, the uncontrollable flooding of the mine with fresh and salty waters began, that resulted in a rapid uneven development of the deep salt karst. In places of fresh water inflow,pillars bases were "undercut" by leaching and the pillars quickly lost bearing capacity.

A year later, the first concentric cracks appeared on the Earth's surface near the shafts and later multiple small concentric craters, which testified to the beginning of the process of the rock mass total destruction over the mine workings.

Over the next 8 years, the destruction of the rock massif over the flooded mine workings and the
Earth's surface degradation developed very dynamically. By 1946 the Earth's surface over the mine transformed into numerous predominantly concentric terraces framing multiple smalldips, sinkholes and collapse pits of different morphology, unevenly distributed over the area. Collapses constantly changed shapes and sizes, small dips merged forming depressions of huge areas. The maximum surface destructions occurred in the north-western part of the minefield where the shafts were located. The largest joint ellipse-shaped sinkhole with dimensions of more than $250 \mathrm{~m}$ (this is the collapse crater \# 1 on the contemporary maps) has been created in this site (Fig. 3). The formed large cavity swallowed up the heapstead buildings, facilities, and equipment including the electrical substation.

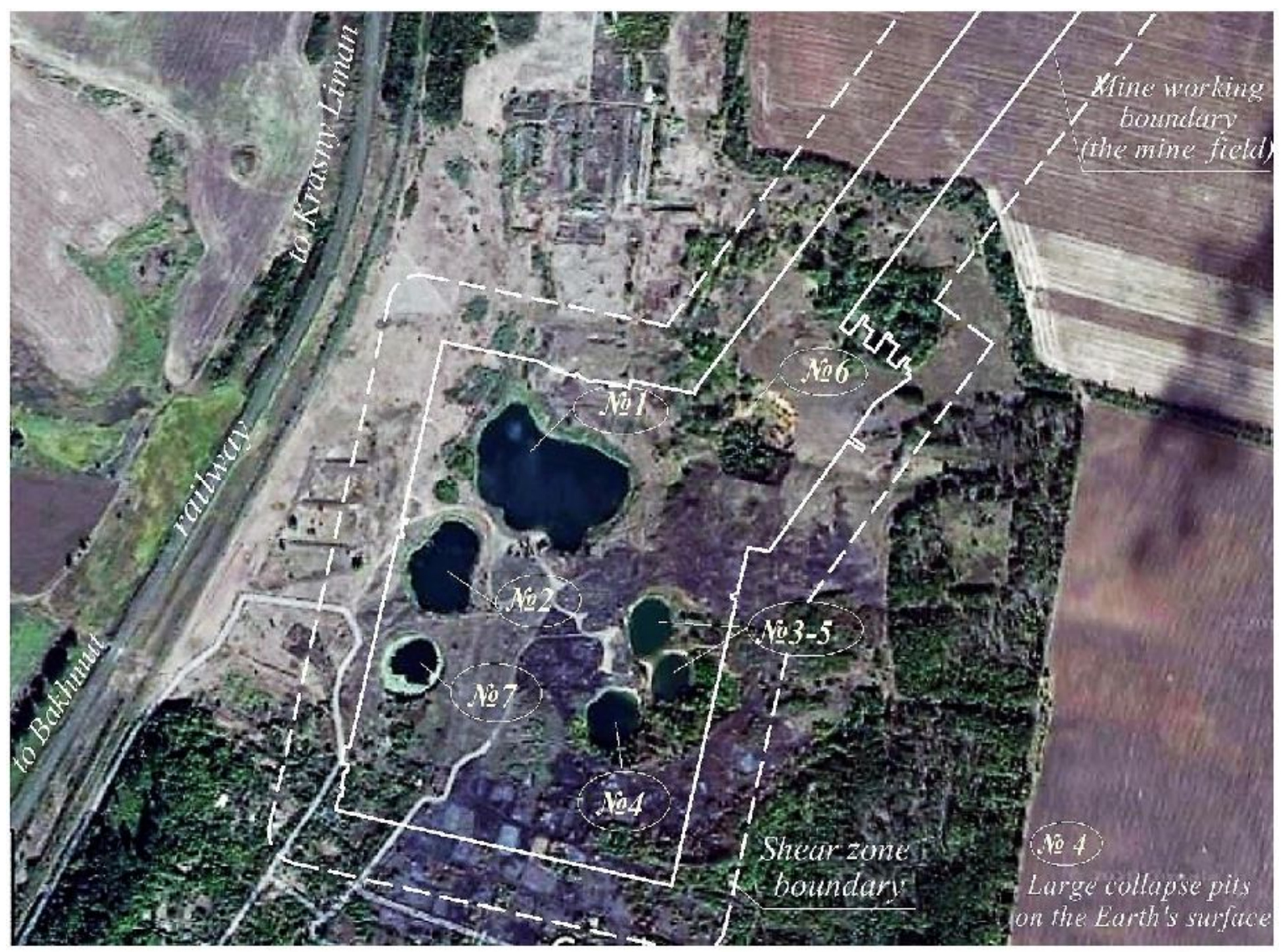

Fig. 3. The modern air photo of the flooded Shevchenko mine area (https://map.online.ua/)

After completion of flooding, during the period from 1950 to 1970 , the cracking processes on the surface were initiated with gradual decrease in speed with increasing time intervals. The deformations were gradually stabilizing in the next 25 years. They showed themselves in uneven subsidence of the certain surface sites. It led to a change in the outlines of the existing collapse pits.

In 1995 (54 years after the beginning of the mine flooding), against the conviction of the relative stabilization of the geomechanical strain, sudden (momentary) collapse of Earth's surface over the north-eastern part of the mine field occurred result-ing in the huge cylindrical sinkhole with depth about $30 \mathrm{~m}$ and with vertical walls (collapse pit \# 6, see Fig. 3). The latest collapse pit (\# 7) was formed in 2012. Salty or saltish lakes arose in all sinkhole craters in different time. The exception is only collapse pit \# 6 located at the elevated terrace. Currently, the entire area above the minefield is in the state of uneven intense deformation condition.

Material and Methods. Synergetic principles (Khomenko, 2007) in reference to modern methodological approaches to ecologically secure man- 
made intervention into salt massifs have been used for evaluation of today's conditions of the Shevchenko salt mine TGS (technogenic geological system). The main methodological principles of the correct exploitation of salt massifs and evaluation of the consequences of the incorrect one have been vividly discussed in the current scientific literature (Jeremic, 1994; Karimi-Jafari et al, 2008; Bosevska, 2010; Khrushchov et al, 2010; Moghadam, et al., 2012; Mechanical, 2012; Khrushchov and Bosevska, 2014; Toderas, 2013; Kortas, 2014 and others). The views of scientists from different countries do not have significant contradictions, but only complement each other and have several aspects focusing on the specific problems of this area. The international experience of assessing the consequences of salt mines flooding shows general regularity of disturbances in the geological environment and trends in the deformation process development on the Earth's surface. At the same time, different geological features of the territories and mining technical conditions for the construction of various engineering facilities determine the formation of various TGS (Tenison, 2016).

Shevchenko salt mine TGS is presented as the analog ecological-mining-geological model, which adequately reflects all the elements of this system, including the identified processes and phenomena occurring within the system, their interrelation and development, as well as the interaction of the system with external factors.

In order to develop the model, classicalmethodsof background analysis were applied:

$>$ compilation of data from all types of ecological-geological works carried out on the territory, and data on methods and technology of the deposit exploitation (Bosevska and Mischenko, 2009; Bosevska, 2010; Khomenko, 2007; Yeschenko et al, 2011);

$>$ qualitative evaluation of the functional properties of rock salt, first of all, its protectability from technogenic karst (Cooper, 2002; Gutiérrez et al, 2008; Khrushchov et al, 2009, 2010);

assessment of the long-term geomechanical stability of mine workings system within salt bed, based on proven calculation methods (Savchenko and Seraya, 1970; Baryakh et al, 1996; Asanov, 2010; Metodicheskie, 1997; Moghadam, 2012);

$>$ analysis of the results of prolonged local complex ecological-mining-geological monitoring (Lee and Sakalas, 2001; Brooks et al, 2006; Korolyov, 2007; Shefchik et al, 2011; Pringle et al, 2012; Gessert, 2013; Cała et al, 2017; Desir, 2018);

$>$ ecological audit: identification of geological environment disturbances caused by salt massif deformation; ecological risks evaluation and fore- casting (Cooper, 2002; Khrushchov et al, 2010).The data for model development are as follows:

1 - the results of the series of the geological exploration, hydrogeological, karstological and geophysical studies (PSA "Donbassgeology", the Ukrainian Salt Research Institute (USRI)) performed in the 1980s and 1990s due to the urgent need to assess threats to infrastructure, namely: of the nearby railway section;

2 - the results of the integrated monitoring conducted by the USRI from the early 1980s including geomorphologic, hydrogeological (terminated after the stabilization of the hydrogeological situation), hydrological and geomechanical observations.

Hydrogeological works had been performed in a net of deep paired observation wells with a full cycle of experimental work (17 wells in total).

Geomechanical monitoring is a traditional instrumental tracking of the Earth's surface subsidence using the system of ground levelling marks oriented along the observed levelled lines. This type of work is being carried out annually since 1965 (since 1994 frequency is two times a year). The installation of instrument tracking lines, the volume and composition of annual observations are periodically adjusted and regulated by a number of normative documents and recommendations.

The basic postulate for assessing the situation and interpreting all initial data is the following proved tenet: geological environment straining always accompanies the creation of engineer facilities in salt massifs. The main factors for assessment of the strain are geomechanical and hydrogeological implying the development of man-made karst (Bosevska, 2010).

Deformations associated with salt karst can develop only in the unprotected, from the aggressive waters penetration, parts of the salt massif (Khrushchov et al, 2009). The rate and trends of these deformations are important in understanding the salt karst theory (Korotkevich, 1970).

The multi stage geomechanical deformations always take place during the transition of salt massifs into a strained-deformed state due to high plastic properties and specific rheological characteristics of rock salt. The mechanical behavior of rock salt in a strained state is very complex because of its tendency to flow or creep when subjected to a shear stress. Rock salt creep property research has been the subject of a large number of studies (Pfeifle and Senseny, 1982; Jeremic, 1994; Mechanical, 2012; Cała, 2017 and others). As is well known, rock salt responds on loading with different creep rates (transient or steady) in a manner nearly equivalent mechanically dependent upon the deformation stage and the pillar loads. The creep rate 
may be large enough. The consequence of creeping is gradual compression of the bearing pillars in situ (reduction of their height and dilatancy), the inherited shifting of the entire over-salt rock mass and the subsidence of the Earth's surface. At the last stage of plastic deformations, creep is characterized by accelerating creep rates and, finally, rock salt pillar failure by rupture. In plastic deformation, the continuity of the deformed pillars is maintained; in ruptural deformation, bearing pillars is broken; a pillar failure occurs and the TGS loses its continuity and stability. It may result in significant disturbances of the geological environment, degradation of the Earth's surface with the corresponding threats to the condition of terrestrial objects and the ecological balance of the territory overall (Brooks et al., 2006; Khrushchov,2014).

Taking into account the unique properties of the salt environment and its ability to change during the change of external factors without fracture, the stable condition of the TGS is the state of slow safe plastic deformations of the salt mass without disturbing its continuity, resulting in a slow safe subsidence of the Earth's surface (several mm per year). The areas of the geological environment, which have lost integrity because of the development of destructive processes, are unsuitable for further use. Destructed parts of salt massif and adjacent geological environment are excluded from being further used.

Results and Discussion. The ecological-mininggeological model of Shevchenko salt mine's TGS. This TGS is composed of four large interconnected elements: 1 - part of the salt bed (BB) containing the mining workings; 2 - the geological environment above the mine workings and within the zone of the influence of mine workings; 3 - Earth's surface over the mine field; 4 - surface waters represented by lakes in sinkholes (collapse craters).

The part of the salt bed $(B B)$ containing the mining workings. It includes 3 elements: 1 - void space (mine workings filled with brines); 2 - load bearing pillars of rock salt; 3 - intact salt mass surrounding the mine workings.

1. Mine workings are located at a depth of more than $120 \mathrm{~m}$ (up to the roof) and are mostly destroyed. To date, some mine workings are filled with over-salt rocks caved in the worked-out rooms. The rest of the underground space of the mine workings is filled with saturated chloride sodium brines of mineralization up to $320 \mathrm{~g} / \mathrm{l}$ being in congestive regime. Obviously, in the stable rooms, the cushions of trapped air are created at the roof. Since the roof of the flooded rooms is approximately $50 \mathrm{~m}$ below the active water exchange zone, under the hydrogeological circumstances, mine brines cannot be involved in the active groundwater movement; and expansion of mine workings con- tour in terms of karst is impossible even hypothetically. This is confirmed by the results of performed geophysical studies. The hydraulical connection of the saturated mine brines and upper aquifers is oneway: the brines can penetrate the collapse cracks and enter into the upper aquifers due to extrusion during rock collapse.

The flooding of the mine took a long time. The ratio of the volumes of mine workings and known indicators of water inflows make it possible to estimate that the mine flooding lasted about 10 years at least. Flooding occurred by fresh and salty waters through the mine shafts with a stable hydrogeological regime of incoming water, as the supplying aquifers had relatively stable hydrodynamic and hydrochemical parameters.

A feature of the flooding was the differentiation of the incoming water: fresh water was mainly flowing along the main shaft \# 1 , while the salty waters of the leaching zone came mainly along the shaft \# 2. It led to the development of rapid technogenic karst and leaching of the pillars bases (undercutting them) near the shaft \# 1 and the loss of their bearing capacity. Therefore, the first sinkhole around the main shafts was formed a year after the beginning of flooding.

At once, the mineralization increasing of incoming fresh waters occurred directly near the mine shafts; and salty waters flowed the other parts of mine field. Thus, in general, for the most part of the minefield, the flooding regime is defined as a gradual, uniformly time-based rise in the level of saltish water at a rate corresponding to the linear dissolution rate of rock salt (Cherevko, 2006).

USRI investigated the influence of such flooding regime on the state of mine workings and on the bearing capacity of the pillars after the completion of flooding by the means of mathematical modeling by the finite element method and modeling based on natural materials (rock salt of the Bryantsevsky bed).

The results of complex modelling showed the following: in the flooding process, uniform leaching of the lateral surface of the pillars took place; the depth of leaching penetration into the pillar massif did not exceed $10 \%$ of its width. As a result, an insignificant change in strain tensor in the elements of the bearing structure occurred: vertical stresses increased by $6 \%$, horizontal stresses increased by $1.5-2.0 \%$, maximum tangential ones increased by $3 \%$. In contexts of a slight decrease in the pillars width and a slight increase in strains, the calculated strength of the massif decreased by approximately $15 \%$, which could lead to a decrease in the bearing capacity of the structure. However, the study of the influence of saturated brine on the pillars bearing capacity after completion of flooding showed a significant increase in horizontal stresses 
while maintaining the distribution pattern of the vertical and maximum tangential stresses. It means that brine pressure on the pillar lateral surface contributed to the strengthening of the edge zone of the whole pillars, since horizontal stresses in the pillars became compressive ones under the effect of brine. The concentration coefficients of vertical stresses were reduced by about 5\% (Cherevko, 2006).

Thus, for the conditions of the Shevchenko mine, the uniform decrease in the pillars width is compensated by the pressure of the saturated brine on their walls in a certain approximation.

It makes it possible to evaluate the bearing capacity of the flooded mine structure without taking into account the changes in the parameters during theflooding process and the pressure of the brine.

2. The bearing pillars of rock salt react the load being deformed. All of them have undergone different stress changes during mine history. It is known, many factors determines the ultimate load on the rock salt pillars (and the ultimate deformation of pillars). One of the most important factor in determining the pillar stress for the same geological conditions is mine geometry, primarily, pillar sizes and mining parameter ratio (a width-to-height ratio for pillars and chambers). The Figure 4 shows the Shevchenko mine has various geometric parameters for different areas of the entire minefield. That is why the condition of the pillars at different areas significantly differs: by now, a part of the interchamber pillars and safety shelves is completely destroyed, but another part of the pillars are at different stages of the deformation processes. Some of the pillars have a fairly stable geomechanical state characterized by slow plastic deformations, while the other part is at the initial stage of ruptural deformations.

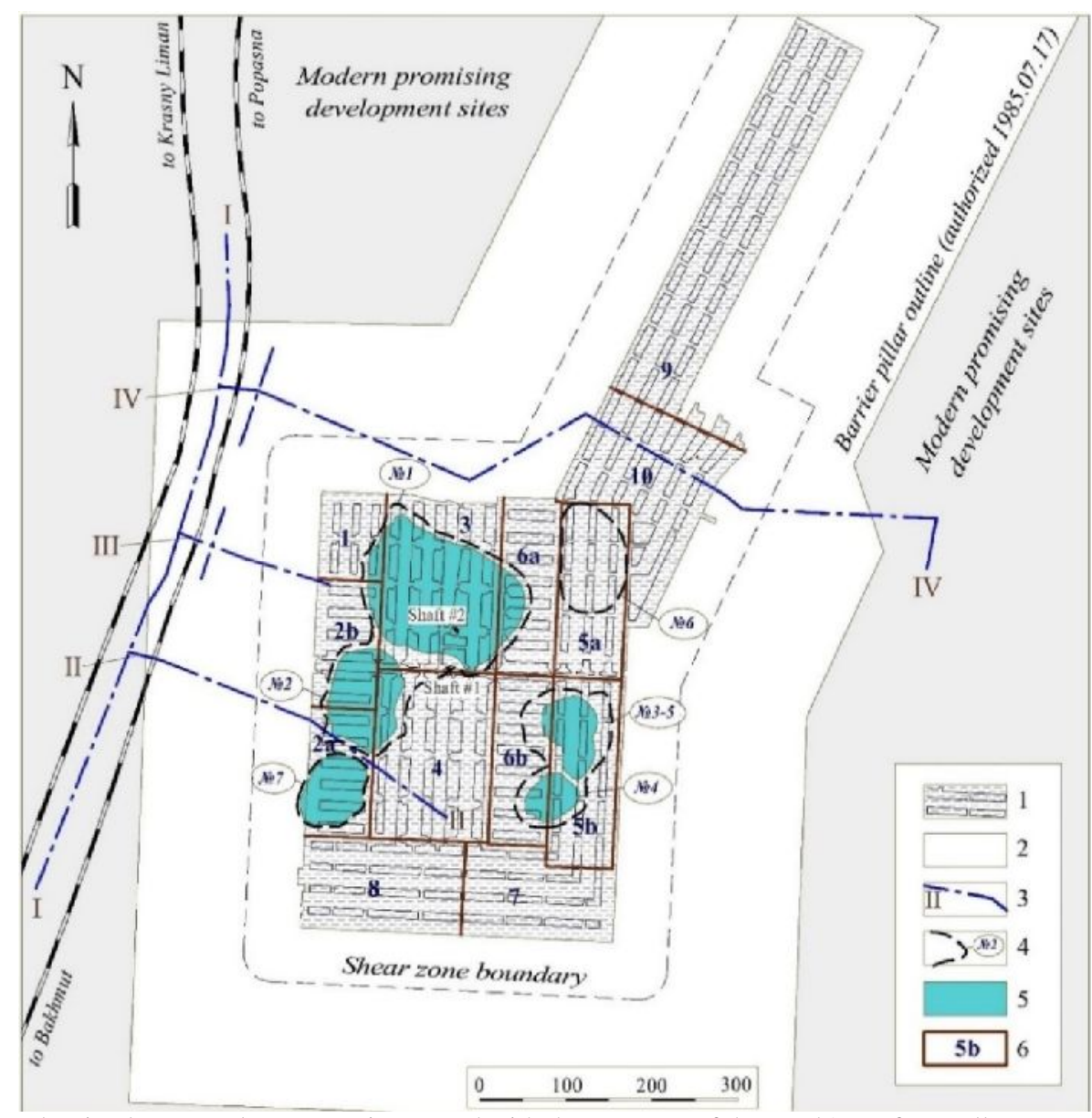

Fig. 4. Shevchenko salt mine layout and geometry integrated with the contours of the Earth's surface collapses 1 - flooded mine workings; 2 - barrier pillar around the mine field for the Bryantsevsky and lower-lying industrial layers approved in 17/07/1985; 3 - modern profile lines of instrumental monitoring of ground subsidence; 4 - the collapse pits on the Earth's surface (and their numbers showing the formation sequence); 5 - lake water surface created in the collapse craters; 6 - mine areas (panels) with different geomechanical characteristics (mining parameter ratio) and their numbers

Therefore, to understand the present deformation processes inside the created TGS and improve deformation forecasts, additional investigation has been performed for the condition assessment of the stability and lifetimes of the load bearing pil-lars all over the minefield. Modern methods of rock salt behavior assessing being applied for the Artyomovsk rock salt deposit (Metodicheskie, 1997) has been used.

It is understood that the lifetimes of the bearing pillars are the period of their plastic deformations without mechanical destruction (without pillar 
failure). The effect of the time factor has been estimated by using the factor of safety of the bearing capacity of the pillars (or the safety factor). The safety factor is determined by many criteria. The most important of which are the geometry of the mine workings (parameters of the rooms and pillars) and their depth since these criteria deter-mine the strain tensors and the initial point of destruction of the massif in time.

Forecasted lifetimes of constructive elements of development system for Artyomovsk rock salt deposit $\left(t_{p}\right)$ are calculated on the basis of the equation of the rock salt state, using the theory of continuity Voltaire - Rabotnov (Metodicheskie, 1997):

$$
t_{p}=0,317 \cdot 10^{-7} \cdot\left[\frac{(n-1) \cdot(1-\alpha)}{\delta}\right]^{\frac{1}{1-\alpha}},
$$

where $\alpha$ and $\delta$-rheological parameters of rock salt determined empirically for rock salt of the BB in the lab of the USRI; $n$ - safety factor calculated for real mining and geological conditions with an allowance for room parameters, the full overburden weight, strength and rheological characteristics of the $\mathrm{BB}$ rock salt.

Since the minefield consists of several panels with different characteristics, it was divided into sections of similar conditions for performing calculations (see Fig. 4). Within each section, the pillars are of the same height, the rooms are of the same width, and the roof depth differs by no more than 5\%.

The pillar safety factors have been calculated for every sites using specially created computer program:

$$
n=\frac{\sum_{j} S_{j} \cdot \sigma_{\mathrm{c} j}}{H \cdot S \cdot \gamma},
$$

where $S$ - the area of the horizontal intersection of rock mass supported by supporting pillars, $\mathrm{m}^{2} ; S_{j}-$ the bearing area of the horizontal section of the pillars (without correction for the decrease due to leaching), $\mathrm{m}^{2} ; H-$ room depth $=$ the thickness of the rocks from the Earth's surface to the roof of workings, $m ; \gamma$ bulk density of rocks, which are supported by the pillars, $\mathrm{N} / \mathrm{m}^{3} ; \sigma_{c j}$ - the strength of rock salt pillar taking into account the ratio of its geometrical dimensions, $\mathrm{Pa}$ :

$$
\sigma_{c j}=\sigma_{c} \cdot K_{1} \cdot K_{2},
$$

where $\sigma_{c}$ - average limit compressive strength of rock salt of the $\mathrm{BB}, \mathrm{P}$ (the value obtained for dry salt is used, since the softening factor of the rock salt is equal to 1 - research data for rock salt of the BB, VNIIG, Yu.P. Shokin, 1964; Asanov, 2010); $1, \quad 2$ - the coefficient of a pillar shape with a supporting area $S_{j}: \quad{ }^{-}$load coefficient $\left(K_{l}=0.8\right.$ provided that the selected area is surrounded by an untouched massif from? at least two sides and its smaller linear size is less than the mine workings depth; $K_{l}=1$ in the remaining cases); 2 - coefficient expressing the dependence of rock salt compressive strength from? the ratio of the geometric parameters of pillars; for riband pillars of the Artyomovsk deposit (length-to-width ratio >10) this coefficient is a constant equal to 1.2.

The predicted pillars lifetimes corresponding to the beginning of the ruptural deformations and mechanical destruction of the pillars of each selected site were determined by formula (1), taking into account the calculated safety factors by formulas 2 and 3 (Table 1). As shown above, the first destructions of the pillars and the Earth's surface above them immediately after the beginning of flooding were associated with the development of man-made karst that "undercut" the pillars and sharply reduced their bearing capacity. These destructions lasted for not less than 20 years with fading speed. The pillars undisturbed by karst continued to deform at different rates, due to the mining and technical conditions of each site.

\begin{tabular}{|c|c|c|c|c|c|c|}
\hline $\begin{array}{l}\text { Mine's panel } \\
\text { number (see } \\
\text { Fig. 4) }\end{array}$ & \begin{tabular}{|l} 
Depth of \\
mine \\
workings, \\
$\mathrm{m}$ \\
\end{tabular} & $\begin{array}{l}\text { Calculated } \\
\text { safety } \\
\text { factors }\end{array}$ & $\begin{array}{c}\text { Calculated } \\
\text { pillars' } \\
\text { lifetimes, years }\end{array}$ & $\begin{array}{c}\text { Period of site development } \\
\text { (according to available } \\
\text { archival data) } \\
\text { years }\end{array}$ & $\begin{array}{c}\text { The time when } \\
\text { the pillars' lifetimes is } \\
\text { completely used, years }\end{array}$ & $\begin{array}{l}\text { Date of destruction } \\
\text { of the earth's surface } \\
\text { above the site }\end{array}$ \\
\hline 1 & 132.5 & 2.45 & 90 & unknown, $\approx$ before 1910 & $\approx 2000$ & $\approx 1950 \mathrm{~s} *$ \\
\hline 2 & 131.0 & 2.45 & 90 & $1910-1917$ & $2000-2007$ & $\approx 1960 \mathrm{~s} *$ and $2012 * *$ \\
\hline $2 b$ & 131.0 & 2.45 & 90 & unknown, $\approx$ before 1910 & $\approx 2000$ & $\approx 1950 \mathrm{~s}-1970 \mathrm{~s} *$ \\
\hline 3 & 120.0 & 2.90 & 260 & unknown, $\approx 1892-1904$ & $\approx 2152-2164$ & $1942 *$ \\
\hline 4 & 125.0 & 2.60 & 130 & $\begin{array}{ll}\text { about } & 1892-1909 \\
\end{array}$ & $\approx 2022-2039$ & - \\
\hline 5 & 145.0 & 2.36 & 70 & unknown, $\approx 1917-1926$ & $\approx 1987-1996$ & $1995 * *$ \\
\hline $5 b$ & 145.0 & 2.33 & 65 & about $\quad 1926-1928$ & $\approx 1991-1993$ & $1946^{*}$ \\
\hline 6 & 140.0 & 2.50 & 100 & unknown, $\approx$ before 1908 & $\approx 2008$ & $1950 *$ \\
\hline $6 b$ & 140.0 & 2.44 & 85 & about $\quad 1892-1909$ & $\approx 1977-1994$ & $1946^{*}$ \\
\hline 7 & 140.0 & 2.43 & 85 & $1929-1930$ & $\approx 2014-2015$ & 2014** \\
\hline 8 & 130.0 & 2.66 & 145 & $1931-1933$ & $\approx 2076-2078$ & - \\
\hline 9 & 167.0 & 2.94 & 260 & $1938-1940$ & $\approx 2198-2200$ & - \\
\hline 10 & 160.0 & 2.63 & 130 & $1936-1941$ & $\approx 2066-2071$ & $\begin{array}{ll}- \\
-\end{array}$ \\
\hline
\end{tabular}

Table 1. Calculated normal safety factors and support pillars lifetimes within the Shevchenko minefield (the sites where the lifetime of rock salt pillars was completed are picked out with grey background)

* sinkholes created due to the technogenic karst undercutting pillars by leaching)

** collapse pits, which have been creating due to the pillars' lifetimes is completely used 
As it can be seen in Table 1, by the beginning of 2000s the pillars' lifetimes within the most part of the minefield were already completely used or near completion. In this regard, a new series of destruction of the pillars and the formation of surface collapses began according to the geomechanical criterion. The destruction mechanism of the pillars and the all over-salt strata is described in detail in a number of works (Khrushchov et al, 2010; Asanov, 2010; Khrushchov and Bosevska, 2014). The main factor of destruction is the excess of rock pressure over the bearing capacity of the rock massif. Destroyed rocks (rock salt and non-salt rocks overlying the $\mathrm{BB}$ ) filled the conforming mine rooms. In the next few years, the destruction of the pillars within the site \# 7 will be completed, in a few more years the destruction of the central part of the minefield (site \# 4), where the formation of a very large collapse is predicted, will begin. Sharp increase of Earth' surface subsidence rate over this mined-out area has already been determined by the results of instrumental monitoring of ground shifts (see below).

It should be underline that the calculated time for finishing of the pillar's lifetime (basic calculations were performed in 1990s) with great accuracy coincides with the time of large surface deformations (including the collapse formation). It is a clear confirmation of the correctness of the accepted methodological approach to ensure environmental safety during the Artyomovsk rock salt deposit development. From the standpoint of modern methodological approaches only support pillars with safety factor 3.0 and more meet the criterion of ensuring long-term stability (300 years and more) (Metodicheskie, 1997). From the standpoint of modern methodological approaches only load bearing pillars with safety factor 3.0 and more meet the criterion of ensuring long-term stability (300 years and more) (Metodicheskie, 1997). Modern mining areas are designed with safety factor 4.0 and more, despite the fact that in consequence it leads to decrease in the extraction ratio of rock salt.

The safety factors of the load-bearing capacity of the Shevchenko mine's pillars are predominantly less than 3.0 with the exception of two sites (\# 3 и \# 9). However the site \# 3 was destroyed in early mine flooding (in 1942) due to leaching of the pillars bases near the mine shaft and the loss of their bearing capacity because of karst. Thereby, if the mine work-ings were not flooded and mine operation continued, this mine would be in an emergency condition due to the loss of pillar stability by the end of 1980s yet. In this case, the issue of measures developing to im-prove the pillars stability (e.g. by the method of backfilled of mined- out areas) or even mine abandonment (e.g. by method of man-made flooding)

would be up for debate.

3. The salt massif of the BB surrounding the minefield is not disturbed, stable and practically does not suffer changes. It has been confirmed by geophysical studies. Within the sections of the salt bed bordering the mined-out areas, the strain tensors are slightly modified, but it does not affect the stable time-dependent condition of the surrounding massif as a whole. The karst processes are also excluded because the leaching zone of the BB is removed to the east of the mine workings outline for a distance of $1.8-2.5 \mathrm{~km}$. In connection with this, an increase in the minefield area is impossible.

The geological environment above the mine workings. In the undisturbed state, it was composed of easily deformable or brittle rocks, which are alternation of karst cavernous gypsum, cracked anhydrite, siltstone, argillite and clay. These rocks are not able to form stable "bridges" over voids, and therefore are prone to rapid destruction inherited from the destructed parts of the salt bed.

In this regard, the geological environment site in the impacted zone of the flooded mine is subject to complex technogenic disturbances, which are 1. Mechanical, 2. Hydrogeological, and 3. Geochemical (Khrushchov, et al, 2010).

1. 1. The mechanical disturbances include the following processes: large vertical shifts of rock slabs, crack growth, and crushing and grinding of the rock. Disruptive disturbances are activated cyclically and usually accompany the rock salt pillars collapse with a possible slight backlog in time (from several days to several months). The main acting factor for mechanical disturbances is the action of overburden pressure.

The long deformational processes occurring inside the rock mass are very uneven in area extent and over time. It is due to the difference in the bearing capacity of rock salt pillars. After failure of the bearing support, the accumulation of stress in the rock mass over the formed cavities occurs before the threshold limit of the geomechanical stability is reached, after which ruptural deformation of a corresponding block of the overlying rock mass begins.

To date, the entire massif of rocks over the minefield has been degraded; it has lost continuity and is divided into separate blocks with different varying geodynamic characteristics. Seismic exploration has showed that the largest disturbances in the massif are the system of deep subvertical cracks sep-arating large rock blocks. The mechanisms of deformation in each block differ somewhat depending on its position in the geological cross-section 
and deformation dynamics. With instant vertical movements such as natural vertical fault, some blocks still retain the primary layered structure. However, predomi-nantly every block are composed of shattered and redeployed rocks.

Deformations of the overlying rocks are greatly enhanced in connection with the ongoing general process of rock shifting (subsidence) as a result of plastic compression deformation of the remaining ("working") rock salt pillars. These deformations are also unevenly redistributed over the area due to different safety factors at different parts of the minefield ranging from 2.45 to 2.9 (see Table 1). Various deformation mechanisms of the overlying strata at the boundary of these blocks are superimposed with a cumulative effect.

Described condition of the overlying strata within the Shevchenko TGS is confirmed by all kinds of geophysical studies: gravitational and electric fields show instability, noticeable changes within the zones of increased cracking and indicate the continuing loss of continuity of rocks with different dynamic.

It should be mentioned in natural undisturbed conditions, there was gypsum karst in this area. We cannot deny the gypsum karst development now; however, it is obviously that changed local geological conditions do not promote gypsum karst processes, but slow down them. Therefore, the formation of large cavities associated with gypsum karst is practically excluded (Cooper, 1996; Cooper, 2002).

2. Hydrogeological disturbances in the overlying strata are secondary. They arose because of the disruption of the massif continuity as a result of which the entire strata of rocks inside the TGS were practically devoid of waterproof properties. The destroyed rock mass comprises a unified aquifer system. The active water exchange zone is above the mine workings by $40-50 \mathrm{~m}$; it does not affect the flooded mine workings. The main stream of the groundwater is subhorizontal and directed to northwest toward the flood plain of the Bakhmut River (see Fig. 1). Its recharge is predominantly water of natural aquifers preserved outside the TGS. Hydraulic connection between the active water exchange zone and saturated salt water in the mine is one-way: the periodic upward flow of brines from the mine workings occurs because of extrusion by the subsiding rock strata and collapsed rocks. Reverse movement of aggressive water from the aquifer system toward the mine workings is impossible because of the lack of drainage conditions (Korotkevich, 1970). In case of huge collapses, saturated brines can rise up to the surface and drain into the lake basins (this process is described below).
3. Geochemical disturbances of the geological environment are associated with the periodic extrusion of saturated brines from the flooded mine workings. Ecological damage is minimal, since under-ground waters in the natural state are also mineralized because of salt and gypsum karst. In addition, as noted above, an aquifer support with highly mineralized brines of the leaching zone of the Above-Bryantsevsky bed takes place. The mineralization of the waters ranges from 156.3 to $310.0 \mathrm{~g} / 1$, so drainage of brines from TGS into adjacent aquifers westerly has practically no effect on the resulting chemical characteristics of natural aquifers. Nevertheless, by the results of calculation using the Dupuy formula the total removal of readily soluble salts from the TGS is about 220 tons / year.

Earth's surface over the minefield. Before the flooding of the mine began, the relief of the Earth's surface was flat, slightly hilly. The ongoing deformations of the rock mass are provoking a constant change in the geomorphological appearance of the over-mine area. Currently all surface deformations are associated with the uneven rock salt pillars' deformations and the inherited collapse of the overlying strata. The surface shapes clearly reflect large deep deformations due to the geological features of the rocks (predominantly loose deposits). Only little localized deep collapses could occur without clear evidence at the surface. Therefore, monitoring of the surface condition permits controlling of the deep processes with a high degree of accuracy.

The surface condition monitoring includes a geomorphological monitoring and an instrumental subsidence monitoring, which were being performed for more than 50 years. The results of such a monitoring adequately characterize the development of surface deformations in terms of area, their spatial-temporal patterns, dynamics and the deformation style (Desir, 2018).

Geomorphological monitoring allows us to track the ongoing progressive degradation of the surface within the area, which is the projection of the mine workings on the surface. At the present time, the Earth's surface is intensely dissected; by 2018, there are seven major collapse pits and several pronounced depressions. The approximate dimensions of the largest collapse in the area of the shafts (\# 1, see Fig. 3) are $115 \mathrm{~m} \times 175 \mathrm{~m}$. The main geomorphological forms of relief clearly reflecting deeper deformations are as follows: saucershaped depressions of the surface, subsidence narrow gullies, large fracture cracks, finally, collapse pits with abrupt sides (Fig. 5). The lithological composition of Quaternary sediments (mainly red clays and loams) also predetermined the formation of second-order geo-morphological elements. Their 
formation is associ-ated with natural processes of levelling the primarily abrupt sides of collapses. These processes continue until reaching the repose angle and are manifested in the formation of tempo- rary small geomorphological elements (landslides and breakaway cracks) and proesses (rock shedding, gravity displacement of the remnants) on steep slopes of the collapse craters.

a

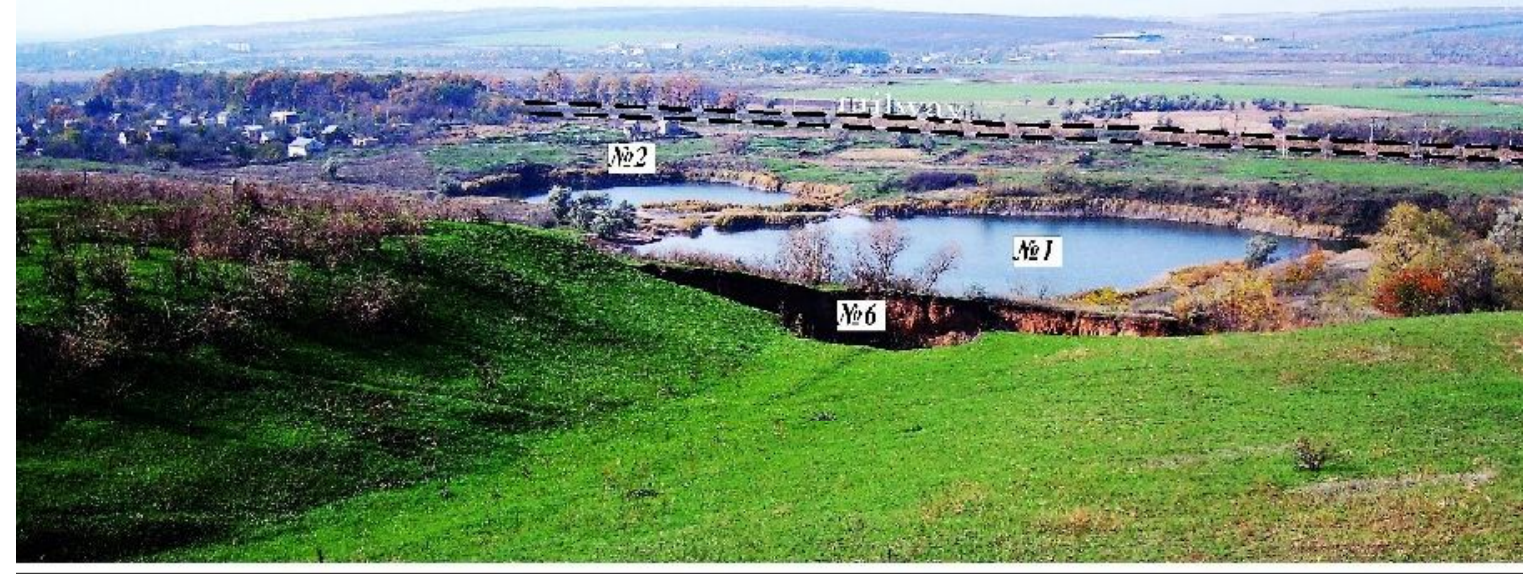

b

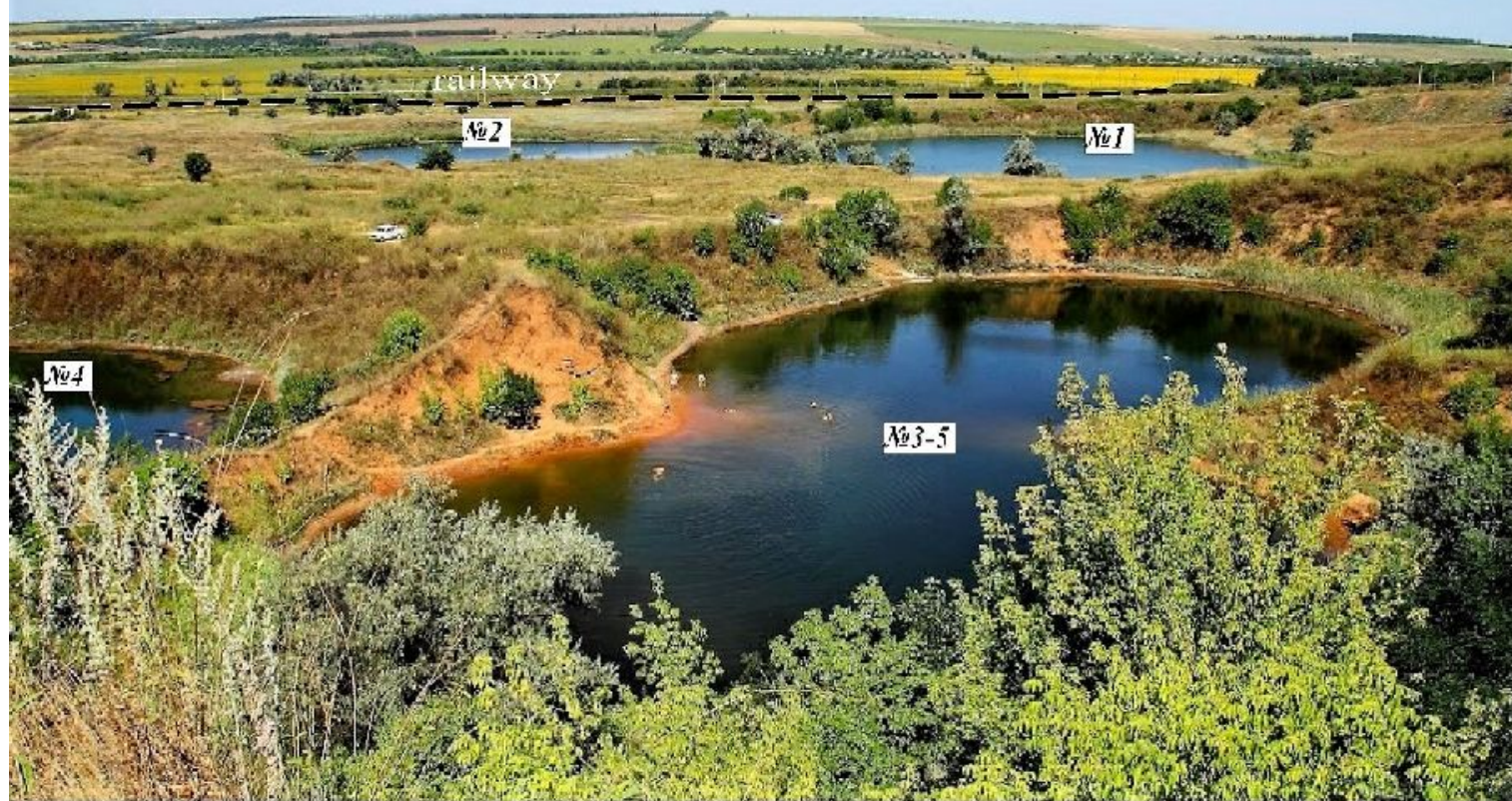

Fig. 5. Modern geomorphological display of the Shevchenko mine TGS: $\mathrm{a}$ - the Northeast view; $\mathrm{b}$ - the Southeast view

In the first stage of disruptive disturbances of the surface, as a result of karst processes (the first 20 years after the beginning of flooding), numerous little sinkholes were formed, which subsequently mer-ged into larger collapse pits.

In subsequent years, the geomechanical factor of new surface disturbance was dominant. In this case, collapse pits are formed usually as a result of a sudden (one-stage) collapse of entire overlying strata. The primary depth of the collapses is proportional with the height of the mine workings up to $30 \mathrm{~m}$, the primary diameter of the collapses are $50 \mathrm{~m}$ and more, the shape is usually round or elliptical. If new large collapses are formed next to the existing, their depths can be less $(12-15 \mathrm{~m})$, and duration of their formation can be bigger, up to a few years. It is due to the fact that the mine workings in these sites were already partially filled with previously collapsed rocks during the formation of adjacent collapses. Figure 6 shows the sequence of formation of a great collapse next to the old sinkholes. 

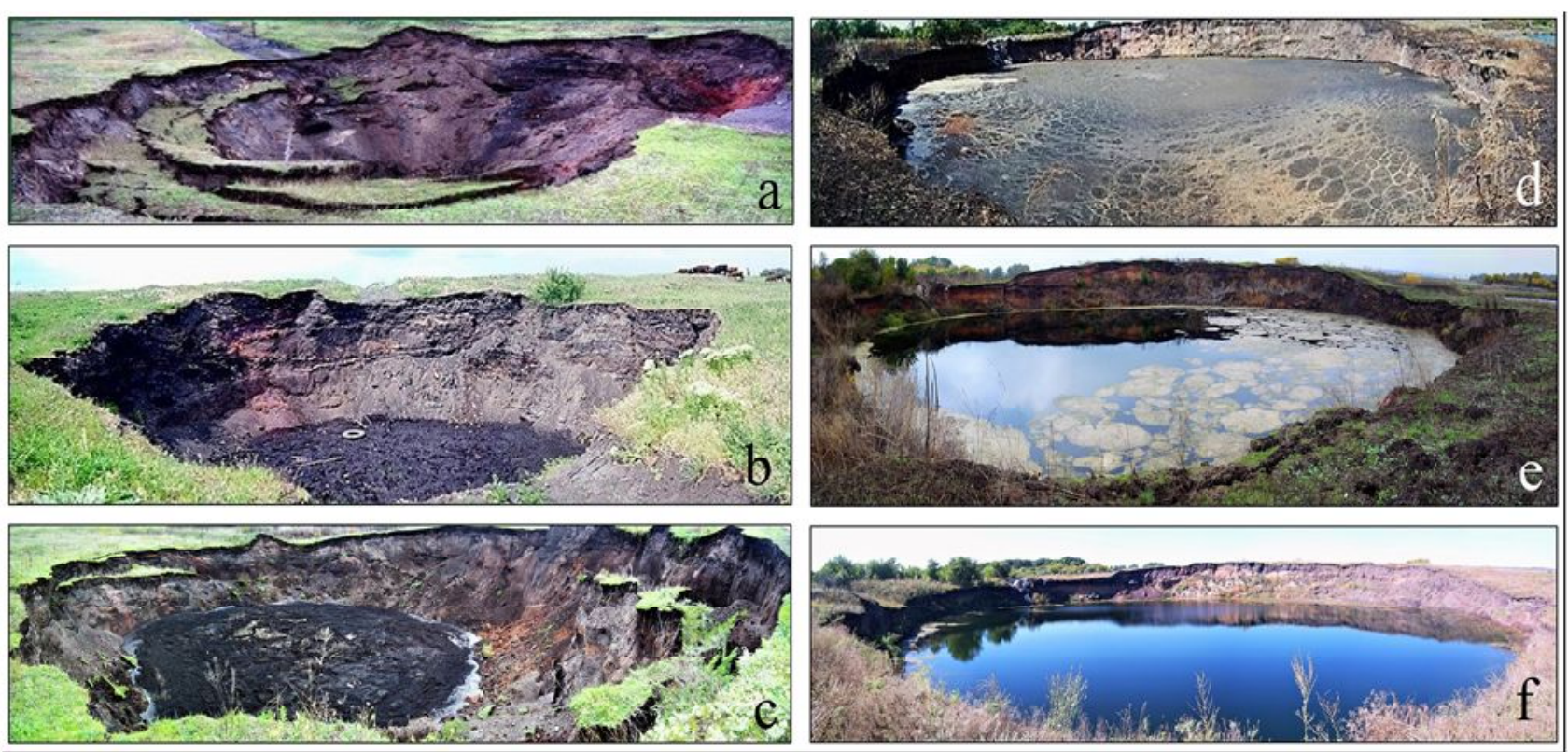

Fig. 6. The developing of the newest collapse 7\# as at: a - December 2012, b - May 2013, c - October 2013, d - September 2014, e - October 2016, f - November 2017

The instrumental monitoring of the Earth's surface subsidence extends beyond the boundaries of the TGS to define the boundaries of the mine influence zone and covers important objects of the infrastructure (e.g. the railway). Modern survey lines of subsidence control are shown in Figure 4. The results of instrumental control show the following:

$>$ the general subsidence trough that covers the entire minefield develops continuously, but unevenly;

$>$ local second and third order troughs are developing within the boundaries of the general subsidence trough;

$>$ deformations of the Earth's surface are localized within the area that is the projection of mine workings on the surface;

$>$ quantitatively, the surface subsidence rate is estimated from 2 to $6 \mathrm{~mm} / \mathrm{year}$ to 400 $\mathrm{mm} /$ year.

Minimum stable subsidence usually takes place over mining sites that are in the steady creep stage and have a very large pillars' lifetime reserve (calculated sites \# 9 and \# 10, leveling line IV IV). Maximum subsidence is usually fixed in period of the initial stage of the pillars destruction; they are a harbinger of the formation of conditions for the surface collapse (see Table $1 \&$ Fig. 4).

At present, dynamic deformation processes develop over the calculated sites \# 7, \# 2a and \# 4 where the pillars' lifetimes was completely used. The approximate pillars' lifetime of the site \# 7 (southeastern part of the minefield) had expired in 2015. Since 2014, geomorphological monitoring has recorded the formation of large surface discon- tinuities in the form of a network of parallel cracks of varying degrees of expansion. Cracks are oriented along the long axis of the mine rooms. The development of cracks are still progressive. The largest cracks-ruptures reach a length of $200 \mathrm{~m}$ and are outlined by ravines.

The deformations of the surface within sites \# 2a and \# 4 are monitored by instrumental subsidence monitoring along the leveling line II - II. The calculated pillars' lifetime at the site \# 2a was completed in 2007. Sharp increase in the dynamics of surface subsidence over this site with the formation of a local trough was recorded in the mid-1990s, when the subsidence increased to $35-55 \mathrm{~mm} /$ year. Further formation of the shift trough was accompanied by an increase in the subsidence rate in its central part (leveling marks \# 197 - \# 201) to 400 - $500 \mathrm{~mm} /$ year $(2011$ - 2012). In 2012, a collapse crater with a diameter of $15 \mathrm{~m}$ and a depth of $13 \mathrm{~m}$ occurred (collapse \# 7, see Fig. 3), after which the subsidence of the adjacent area began to decrease gradually that corresponds to the stage of compacttion of the collapsed rocks.

Five years after the formation of the collapse, there was a decrease in the subsidence rate in the adjacent area within the calculated site \# 2a by more than $40 \%$ of the maximum. Now the collapse is in

the stage of intensive development - secondary geo-morphological processes are superimposed on primary ones. Its dimensions reached a diameter of $80 \mathrm{~m}$ and a salt lake formed in the collapse crater (Fig. 7). 


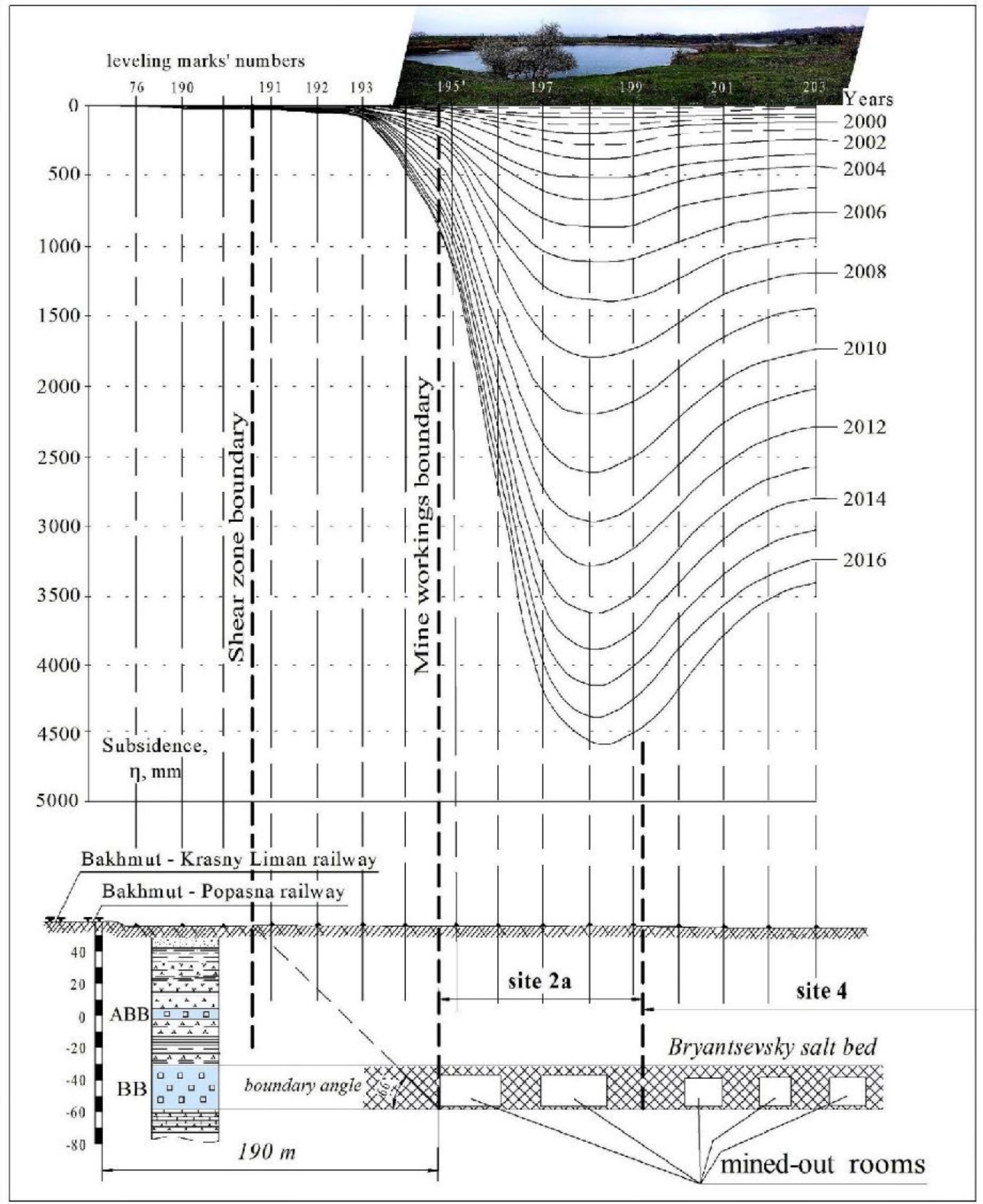

Fig. 7.The graph of Earth's subsidence within the Shevchenko mine TGS taken along line II - II (see Fig. 4)

Deep deformation processes in the central part of the minefield (calculated site \# 4) are reflected in the surface subsidence up to $250 \mathrm{~mm} /$ year that shows the very large strains plastic deformations of the bearing pillars take place (tertiary creep - Phase III). The pillars' lifetime will be completely used in a few years.

Thereby, monitoring of surface deformations makes it possible to control deep deformation processes with high accuracy and confirms the correctness of modern methods of deformation control dur-ing deposit development.
Surface salt lakes were created in 6 basins of large collapse craters (see Fig.3 and Fig. 5). The bed of lake basins is composed mainly of heavy loams and red-colored clays $(\mathrm{Q})$ with very low filtration properties. These rocks arepractically impervious.

The water-salt balance of the lakes is quite simple:a water-budget input is the brine pressed from the mine workings and the underlying brine aquifer complex, and the atmospheric precipitation falling on the lake area and on the limited catchment areas;a water-budget output is the water evaporation and negligible drainage during certain periods when conditions are created for it. The pie- 
zometric levels of the TGS aquiferous complex are generally below the bottom of the lakes, so their unloading into the lake basins is possible only when abrupt rise levels during the large shifts of rock blocks with the formation of new collapses or the rapid development of subsidence on the threshold of new collapses. The depth of the lakes is from seven to $14 \mathrm{~m}$ (from the water surface to the bottom). The lake basins are involved in the general process of lowering the Earth's surface.

In the water-salt regime in all lakes there is a cyclicity corresponding to the cyclic development of deformation processes in the rock mass and the stages of stabilization of the regime and its activation alternate. The stable regime stage of the lakes are characterized with the differentiation of water by mineralization in the absence of ascending flows and accumulation of fine clay particles clogging at the bottom of the lake. The lake basins become quasi-inland, and the lower parts of the lakes turn into a quasi-closed system with a stagnant watersalt regime.

In addition, biota colonies intensively develops in lakes during a periods of long-term stabilization of their regime. These are predominantly moderately halophilic bacteria (such as Paracoccus, Vibrion, othes), which, in order to ensure their vital activity, release a large amount of heat, raising the water temperature in the habitat of their colony. This significantly affects the distribution of the temperature gradient in depth and ensures the formation of a special bio-physical-chemical environment of the stagnant salt lakes (Andrashko and Sharkany, 2002). In this environment, in the absence of oxygen and the presence of hydrogen sulphide the transformation of a finely dispersed clay fraction into a typical black ooze or salt lakes $(\mathrm{FeS})$ occurs, as well as the formation of colloidal solutions, which are complex disperse systems also takes place. The main components of colloids are the true sodium chloride brine, a highly dispersed clay substance, bacteria and microorganisms, as well as residues of their vital functions. All these processes enhance the bottom clogging which en- sures a full waterproofing of the lower part of the lake basin.

Active stages are associated with activation of the rock subsidence processes and subsequent large movements of the slabs, up to the formation of new collapses. During this period, the aquiferous complex is not able to assimilate large portions of mine brines, which come at burst extrusion. As a consequence, squeezing brines into the lake basins through the formed waterways occurs. The salt composition of the incoming brines is dominated by $\mathrm{NaCl}$, which increases the amount of calcium and sulfate ions. The active cycle of the lake regime sharply disturbs the formed bio-physical-chemical environment of the lake. It is characterized by a sharp increase in the mineralization of water (up to $100-150 \mathrm{~g} / \mathrm{l}$ in the bottom layer) and the emergence of brineflows and airflows (squeezed out of air cushions in mine workings) leads to mixing of water layers and temporary equalization of mineralization and water temperature in depth.

Thus, the lake water-salt regime stages clearly reflect the dynamics of development of deformation processes inside TGS already at the initial stages of their activation. Therefore, hydrological monitoring provides significant additional information on the dynamics of development of deep processes. Hydrological monitoring has been carried out continuously, since the 1980s, and includes observations of changes in the hydrochemical and hydrodynamic characteristics of waters in the collapse lakes throughout the depth.

Since the development cycles of all lakes do not coincide in time and the hydraulic connection between the lakes is difficult or absent, the hydrodynamic and hydrochemical regime of all lakes is different. Namely, the level positions in nearby lakes differ by the same moment by $50 \mathrm{~cm}$ or more, the ranges of the mineralization variation with depth are different. The lake bio-physical-chemical environment depending on the amount of biota in different lakes and the local conditions for the development of colonies also differs (Table 2).

Table 2. The main indicators of the chemistry and temperature regime of waters in saline lakes formed over a flooded mine in 2017

\begin{tabular}{|c|c|c|c|c|c|c|c|c|c|}
\hline \multirow[b]{2}{*}{$\begin{array}{c}\text { Lake } \\
\text { number }\end{array}$} & \multirow[b]{2}{*}{ Sampling depth } & \multicolumn{4}{|c|}{ April } & \multicolumn{4}{|c|}{ October } \\
\hline & & $\begin{array}{c}\text { Water } \\
\text { temperature, } \\
\circ\end{array}$ & $\begin{array}{c}\mathrm{CaSO}_{4}, \\
\mathrm{~g} / \mathrm{l}\end{array}$ & $\begin{array}{c}\mathrm{NaCl}, \\
\mathrm{g} / \mathrm{l}\end{array}$ & $\begin{array}{c}\text { total } \\
\text { soluble } \\
\text { salts, } g / 1\end{array}$ & $\begin{array}{c}\text { Water } \\
\text { temperature, } \\
\circ\end{array}$ & $\begin{array}{c}\mathrm{CaSO}_{4}, \\
\mathrm{~g} / \mathrm{l}\end{array}$ & $\begin{array}{c}\mathrm{NaCl}, \\
\mathrm{g} / \mathrm{l}\end{array}$ & $\begin{array}{c}\text { total } \\
\text { soluble } \\
\text { salts, g/l }\end{array}$ \\
\hline \multirow{2}{*}{$1 \#$} & Surface layer & 11,5 & 2,22 & 10,49 & 14,04 & 15,5 & 2,82 & 12,84 & 17,49 \\
\hline & Near-bottom water layer; $8,0 \mathrm{~m}$ & 10,5 & 2,61 & 14,77 & 18,97 & 17,5 & 3,68 & 81,37 & 89,56 \\
\hline \multirow{2}{*}{$2 \#$} & Surface layer & 11,5 & 1,97 & 9,80 & 13,28 & 15,5 & 3,14 & 12,25 & 17,40 \\
\hline & Near-bottom water layer; $12,0 \mathrm{~m}$ & 12,0 & 3,78 & 35,14 & 43,41 & 18,5 & 3,82 & 42,72 & 51,12 \\
\hline \multirow{2}{*}{$3-5 \#$} & Surface layer & 12,0 & 2,37 & 20,09 & 23,90 & 15,0 & 4,21 & 32,48 & 38,73 \\
\hline & Near-bottom water layer; $6,0 \mathrm{~m}$ & 15,5 & 2,90 & 37,76 & 43,59 & 16,0 & 3,85 & 34,27 & 40,51 \\
\hline \multirow{2}{*}{$4 \#$} & Surface layer & 12,0 & 1,51 & 12,25 & 15,26 & 15,0 & 2,39 & 17,65 & 22,30 \\
\hline & Near-bottom water layer; $9,0 \mathrm{~m}$ & 11,0 & 2,29 & 18,40 & 23,21 & 15,5 & 2,38 & 18,38 & 23,32 \\
\hline \multirow{2}{*}{ 7\# } & Surface layer & 12,0 & 1,33 & $\mathbf{7 , 3 5}$ & 11,97 & 15,5 & 1,96 & 10,56 & 14,24 \\
\hline & Near-bottom water layer; $12,0 \mathrm{~m}$ & 12,0 & 5,43 & 82,51 & 90,67 & 17,5 & 4,07 & 54,24 & 60,71 \\
\hline
\end{tabular}


Nevertheless, for regimes of all lakes, the general patterns are noted: the same seasonal fluctuations in water levels, the increase in mineralization with depth and in the seasonal cycle from spring to autumn, the direction of the temperature gradient is increasing towards the top direction during warm season and increasing towards bottom during clod season.

At different stages of lakes development, the mineralization of waters on the lakesurfaces vary between 0.4 and $120 \mathrm{~g} / \mathrm{l}$, and at a depth of $7.0-144$ $\mathrm{g} / \mathrm{l}$. During the entire monitoring period, the highest mineralization was recorded in the bottom layers of lake \# 3 (160 g/l). At the same time, the highest water temperature at the bottom was $+29^{\circ} \mathrm{C}$, while the surface water temperature was $17^{\circ} \mathrm{C}$ (long-term stabilization period). In each time, the highest mineralization is characteristic of lakes located within an actively deformable area. For example, as of 2017 , the highest salinity of the bottom layer was recorded in lake \# 7, which formed at the end (2012), the rock mass site under the lake basin remains in the stage of slow progressive deformations (see Table 2, fig. 6).

It occurs owing to the rise in level during the high water period and the possible emergence of conditions for drainage through non-clogging sides of the collapse (contain thin sand interlayers), the increasing dilution with fresh atmospheric water during expansion of the collapse pit due and the discharge of low-yield aquifers in some areas (e.g. the eastern side of the collapse \# 3, where a fresh water source is periodically formed). The average seasonal fluctuations in the water level in the salt lakes are $0.35 \mathrm{~m}$ with a range of variations from 0.20 to $0.55 \mathrm{~m}$.

Accordingly, despite the spatial proximity of all lakes there is a difference in the bio-physicalchemical environment in each of the salt lake. Any changes in this environment are also a "litmus test" for predicting deformational processes at depth.

Conclusion. Within the territory of the abandoned flooded Shevchenko salt mine, the labile quasiclosed technogenic geological system (TGS) has been formed in which long-term, multi-active destructive processes are occurring. The TGS is limited in area by a nominal enclosed vertical surface, the projection of which coincides with the shear zone boundary. At the bottom the TGS is limited by the base of the spent Bryantsevsky bed.

The driving force of TGS development is the processes of salt massif degradation up to mechanical destruction of the rock salt pillars within the minefield, provoked by hydrogeological and geomechanical factors in series.
All internal elements of the system have a stable one-way connection directed from the bottom up to the earth's surface. The deformation processes are localized within the created system. They do not practically influence the geoecological situation beyond its borders. The binding of TGS and the surrounding rock mass is only carried out through the aquifers in the middle part of the geological section. Some removal of salts from the system is assimilated by the natural brine aquifer of the leaching zone of the overlying AboveBryantsevsky salt bed, which adjoins it from the west closely.

The result of the formation and development of the system is a long destabilization of the relief of the Earth's surface and the formation of unique lakes in the water-salt regime. The active processes of discontinuous deformations and surface collapses will continue unevenly for several tens of years. The deformation processes is expected to complete within a time period of 200 years or more. During this period of 200 years the first $50-60$ years of them are an active period of collapse development in the main isometric part of the minefield. In this period, the geological environment and the Earth's surface within the TGS completely looses their utility for any purposes however the likelihood of creating a threat to the nearby railway section is negligible.

On the one hand, the described deformation processes are typical for the flooded salt mines areas where the supporting rock salt pillars lost their stability. On the other hand, a combination of mining and geological factors has led to the creation of rather unique conditions, when all the negative effects have been localized within the system; while on the surface the salt lakes with a unique bio-physical-chemical environment have been formed. The unusual regime of the lakes with unexpected temperature changes and variable mineralization with the presence of colloids are of great media interest.

The performed assessment of the dynamics of the system development in time confirms the cor-rectness of the taken methodical approach to control mechanical behavior of salt during the Artyomovsk rock salt deposit development. In addition, the results of the investigations can be used to improve the methodology of salt mining in terms of decreasing of environmental risks in the densely populated areas overall as well as to develop of alternate improved safe room-and-pillar mining geometries that provide higher salt extraction while maintaining an appropriate safety factor for this and other rock salt deposits. 
Acknowledgements. The authors express their deep respect and gratitude to the author of the method of scientific control of rock mass deformations during the Artyomovsk rock salt deposit development, the former USRI employee Seraya Alla Romanovna as well as to all authors of works dealing with the deformations of salt strata under the techno-genic impact on them and their monitoring, which was used in this work. In addition, we appreciate to the State Enterprise ARTYOMSOL, which continuously finances scientific and monitoring works within the territory of the abandoned Shevchenko mine for 40 years.

\section{References}

Andrashko, Iu.V., Sharkany, I.P., 2002. Halofilni bakterii ozera Kunihunda - ekzohennyi fotosensybilizator [The halophilic bacteria of Kunihunda Lake is the exogenic fotosensibilizer]. Ukr. journ. of Dermatology, Venereology, Cosmetology, 2, 6 8 (in Ukrainian).

Asanov, V.A., Ievseev, A.V., 2010. Vliyanie rassolov na mekhanicheskiye svoistva solyanykh porod [Brines influence on mechanical properties of rock salt]. Mining information-analitical bulletin, $2,363-366$ (in Russian) = http://www.giabonline.ru/files/Data/2010/2/Asanov_2_2010.pdf

Baryakh, A. ., Konstantinova, S.A., Asanov, V.A., 1996. Deformirovaniye solyanykh porod [Salt rocks deforming]. Iekaterinburg: Mining Institute of RAS, 203 p. (in Russian).

Bosevska,L.P., Mishchenko, S.I., 2009. Vykonannia doslidzhen $\mathrm{z}$ otsinky vplyvu diialnosti solianykh pidpryiemstv Ukrainy na navkolyshnie pryrodne seredovyshche ta rozrobka naukovo obgruntovanykh rekomendatsii i inzhenernykh propozytsii shchodo polipshennia ekolohichnoho stanu terytorii solianykh vyrobnytstv[Carrying out research for the evaluation of environmental impact of the Ukrainian salt mining activities and developing scientifically grounded recommendations and engineering proposals to improve the environment of salt production areas]. Ukr. Salt Research Institute, research report, 95/4, SR 0108U006372, arch. 7125, Artyomovsk (Bakhmut), 185 p. (in Ukrainian).

Bosevska, L.P., 2010. Osnovnye printsipy inzhenernoheolohicheskoi otsenki solyanykh massivov, ispol'zovanie ikh kak sredy dlya sooruzheniya podzemnykh ob'iektov razlychnoho naznacheniya [Basic principles of salt masses engineeringgeological evaluation to use them as an environment for creation of multipurpose underground facilities]. Bul. of the Dnipropetr. Univ. Ser. Geol. Geogr., 12, 95 - 105 (in Russian).

Brooks, T.G., o'Riordan, N.J., Bird, J.F., Stirling, R. \& Billington, D., 2006. Stabilisation of abandoned salt mines in North West England. The Geological Society of London. IAEG2006 Paper number 781.
Cała, M., Tajduś, A., Andrusiewicz, W., Kowalski, M., Kolano, M., Stopkowicz, A., Cyran, K. , Jakobczyk, J., 2017. Long term analysis of deformations in salt mines: KŁODAWA salt mine. Case study, Central Poland. Arch. Min. Sci. 62 (2017), 3, 565 - 577, doi: 10.1515/amsc-20170041

Cherevko, P. I., 2006. Vykonannia kompleksu doslidzhen $\mathrm{z}$ otsinky vplyvu hirnychykh vyrobok solianykh shakht na stan zemnoi poverkhni i pidhotovka naukovo obhruntovanykh rekomendatsii $\mathrm{z}$ konservatsii ta likvidatsii vidpratsovanykh dilianok ta shakht $\mathrm{z}$ minimalnym vplyvom na dovkillia [The accomplishment of complex research works to evaluate the salt mines influence on the Earth's surface condition; the preparation of scientifically-based recommendations for the conservation of the mined-out areas and mine abandonment with minimal environmental impact]. Ukr. Salt Research Institute, research report, 6.05.18, SR 0107U006491, Artyomovsk (Bakhmut), 136 p. (in Ukrainian).

Cooper, Anthony H., 1996. Gypsum karst of Great Britain. International Journal of Speleology, 25 (3-4), 195 - 202, doi: 10.5038/1827-806X.25.3.14

Cooper, A. H., 2002. Halite karst geohazards (natural and man-made) in the United Kingdom. Environmental Geology, 42, 505 - 512 .

Cooper, Anthony H., 2002. Environmental problems caused by gypsum karst and salt karst in Great Britain. Carbonates and Evaporites, vol. 17, 2, 116 - 120, doi: 10.1007 /BF03176477

Desir, G., Gutiérrez, F., Merino, J., Carbonel, D., BenitoCalvo, A., Guerrero, J., Fabregat, I., 2018. Rapid subsidence in damaging sinkholes: Measurement by high-precision leveling and the role of salt dissolution. Geomorphology, vol. 303, 15 February 2018, $393 \quad-\quad 409, \quad$ doi: 10.1016/j.geomorph.2017.12.004

Gessert Astrid, Schicht Thomas, 2013. Seismological and geotechnical long-term monitoring of an abandonedpotash mine. K-UTEC AG Salt Technologies. https://www.kutec.de/fileadmin/redakteur/GY/Dokumente/Artik el_seismic_monitoring_FB_052013.pdf

Gutiérrez, F, Johnson, Kenneth, Cooper, Anthony, 2008. Evaporite-karst processes, landforms, and environmental problems. Environmental Geology, 53 (5), 935 - 936, doi: 10.1007/s00254-007-0715-9

Jeremic, Michael L. 1994. Rock mechanics in salt mining. - Laureutian University, Sudbury, Canada. Rotterdam, Brookfield, VT: Balkema; 532 p., ISBN-13: 978-9054101031.

Karimi-Jafari, M., Bérest, P., Brouard, B. 2008. Subsidence, Sinkholes and Craters above Salt Caverns. SMRI Spring Technical Conference, Porto, Portugal, $269-278$. = http://www.brouardconsulting.com/sites/default/files/Karimi_et_alPorto-2008.pdf

Khomenko, . Ye, 2007. Sinergetika v upravlenii sostojaniem massiva gornych porod [Synergetics using in management of rocks mass state]. Retrieved 
from http://www.rudana.in.ua/sinergetika.htm (accessed 07.04.2017) (in Russian)

Khrushchov, D.P., Bosevska, L.P., Kyrpach, Yu.V., Stepanyuk, O.V., 2009. Metodolohichni ta praktychni aspekty vyznachennia zakhyshchenosti solianykh tovshch [Metodological and practical aspects of salt strata vulnerability definition]. Proc. 5th Int. Scient.-Practical Conf. "Ecological safety: the problems and solution ways". Kharkiv, Raider, vol. 1, 99 - 104 (in Ukrainian)

Khrushchov, D.P., Bosevska, L.P., Kyrpach, Yu.V., Stepanuyk, O.V., 2010. Human made intervention into salt massifs environment: mechanisms, factors, results and ecological problems. An Overview Paper, Int. Conf. "GeoDarmstadt 2010 Geosciences Secure the Future", Darmstadt, Germany (October 10 - 13), 305 - 306.

Khrushchov D.P., Bosevska L.P., 2014. Environmental problems of salt mining in Ukraine. GEM NEWS - Newsletter of the IUGS commission on geoscience for environmental management. No. 22, 11 16.

http://iugs.org/uploads/GEM\%20newsletter\%20N o.\%2022-1.pdf

Korolyov, V.A., 2007. Osnovnye printsipy organizatsii monitoringa geologicheskikh, litotekhnicheskikh i ekologicheskikh system [Basic principles of arrangement monitoring of geological, lithotechnical \& ecological systems]. Geological engineering, December, 24 - 29 (in Russian)

Korotkevich, G.V, 1970. Solyanoi karst [Salt karst]. Leningrad, Nedra, 256 p.

Kortas, Grzegorz, Maj, Agnieszka, 2014. Deformations of the protection shelf in the "Wapno" salt mine, based on model studies. Arch. Min. Sci., Vol. 59 (2014), 4, 869 - 886, doi: 10.2478/amsc-20140060 .

Lee, E. M., Sakalas, C. F., 2001. Subsidence map development in an area of abandoned salt mines. Geological Society, London, Engineering Geology Special Publications, 18, $193-195,2001$, https://doi.org/10.1144/GSL.ENG.2001.018.01.2 7

Mechanical Behavior of Salt VII, 2012. Berest, P., Ghoreychi, M., Hadj-Hassen, F., Tijani, M. (eds). Taylor \& Francis Group, London, CRC Press, March 22, 506 p., ISBN 10: 0415621224 ISBN 13: 978-0-415-62122-9

Metodicheskie ukazaniya po raschetu parametrov sistemy razrabotki svity plastov kamennoy soli Artyomovskogo mestorozhdeniya (normativnyiy dokument) [Methodological agreed guidelines on determination of mining method parameters for salt strata series of the Artyomovsk rock salt deposit (normative document)], 1997. USRI, Se- raya, A.R., Cherevko, P.I., Miroshnichenko, V.G. (eds), Artyomovsk, 99 p. (in Russian).

Moghadam, S. Nazary, Mirzabozorg, H., Noorzad, A. \& Nazokkar, K., 2012. Stability analysis of caverns excavated in heterogeneous salt formations. Indian Journal of Science and Technology, vol. 5, no. 8 (August), 3128 - 3031. ISSN: 0974-6846

Pfeifle, Tom W., Senseny, Paul E., 1982. Steady-State Creep Of Rock Salt In Geoengineering. The 23rd U.S Symposium on Rock Mechanics (USRMS), 25 - 27 August, Berkeley, California. American Rock Mechanics Association, ARMA-82-307.

Pringle, J.K., Styles, P., Howell, C.P., Branston, M.W., Furner, R., Toon, S.M., 2012. Case History. Long-term time-lapse microgravity and geotechnical monitoring of relict salt mines, Marston, Cheshire, U.K. Geophysics, vol. 77, 6 (Nov. Dec. 2012); B287-B294, doi: 10.1190/GEO20110491.1.

Savchenko, A.Ph., Seraya, A.R., 1970. Rezul'taty issledovaniya prochnostnych svoistv kamennoi soli Artyomovskogo mestorozhdeniya [Results of the research strength properties of rock salt from Artyomovsk rock salt deposit]. All-Union research Inst.'s works; is. 14(22), part 1, Artyomovsk: ONTI VNIISOL, 14 - 17 (in Russian)

Shefchik, B., Tomes, R., Belli, R., 2011. Salt Cavern Monitoring System for Early Warning of Sinkhole Formation. Geotechnical News. December 2011, $30-33$.

Tenison, L. O., 2016. Prognozirovanie vertikal'nykh deformatsiy zemnoi poverkhnosti $\mathrm{v}$ usloviyakh zatoplennogo rudnika BKPRU - 1 [Forecasting of the earth's surface vertical deformations under the flooded mine BKPRU - 1]. Mining inform.analit. bul., \#1, 230 - 242 (in Russian) = http://www.giabonline.ru/files/Data/2016/1/230_242_1_2016.pdf

Toderas, M., 2013. The Stability of the Underground Structures Achieved in Salt Massif and TheirMonitoring. World Scientific and Engineering Academy and Society (WSEAS) - Recent Advances in Civil and MiningEngineering, Proc. $1^{\text {st }}$ Europ. Conf. of Mining Engineering (MINENG '13), Antalya,Turkey, Oct. 8 - 10, 2013, 41 - 51, ISSN 2227-4588; ISBN 978-960-474$337-7$

Yeschenko, A.N., Dotsenko, D.N., Eschenko, S.A., 2011. Podzemnaya dobycha kamennoi soli na Artyomovskom mestorozhdenii [Underground extraction of rock salt at the Artyomovsk deposit]. Donetsk, Nord-Press, 144 p. (in Russian). 